\title{
Effect of maternal preeclampsia on neonatal red cell parameters
}

\author{
Samreen Farooqui ${ }^{1}$, Abdus Salam², Eqbal Anwer ${ }^{3}$, Pooja Ojha ${ }^{4}$, Seema Singh ${ }^{5, *}$ \\ ${ }^{1}$ PG Student, ${ }^{2,3}$ Associate Professor, ${ }^{4}$ Assistant Professor, ${ }^{5}$ Professor \& HOD, Dept. of Physiology, Era's Lucknow \\ Medical College \& Hospital, Lucknow, India \\ *Corresponding Author: \\ Email: singh_seema2007@yahoo.com
}

\begin{abstract}
Aim and Objectives: The aim of this study was to assess and compare the changes in haematological parameters in neonates using cord blood from preeclamptic and from normal pregnancies.

Materials and Methods: This is a cross sectional study based on Umbilical Cord Blood (UCB) samples taken from 40 preeclamptic and 40 normal pregnancies. $2 \mathrm{ml}$ cord blood was collected immediately after delivery and transferred into an EDTA vial for CBC analysis and reticulocyte count was done using brilliant cresyl blue. The data entry and analysis was done on Microsoft Office Excel 2007. In all statistical analysis a p value $<0.05$ was considered significant.

Results: RBC, Reticulocyte count, Reticulocyte Production Index (RPI) were found to be higher in neonatal cord blood from preeclamptic females than those from normal pregnancies. Haemoglobin and Haematocrit were found to be lower in neonatal cord blood from preeclamptic pregnancies.

Conclusion: Newborns of preeclamptic mothers should be carefully monitored in terms of hematologic abnormalities. Thus, suspecting a deranged haematological profile early in the course of disease will be of great help in the preemptive management strategies that have proven to be playing a crucial role time and again in reducing the morbidities and mortalities associated with Preeclampsia.
\end{abstract}

Keywords: Cord blood, Preeclampsia, RBC, Reticulocyte, RPI.

Received: $20^{\text {th }}$ September, 2017

\section{Introduction}

Preeclampsia is defined as onset of hypertension (more than or equal to $140 / 90 \mathrm{~mm}$ of $\mathrm{Hg}$ ) associated with proteinuria (more than or equal to $300 \mathrm{mg}$ per $24 \mathrm{hrs}$ ) after 20 weeks gestation in a previously normotensive pregnant woman. $^{1-4}$ Typically, preeclampsia is asymptomatic, but in its most severe form, it may also be present with headache, epigastric pain, visual disturbances and changes in consciousness. ${ }^{1,3}$

Preeclampsia complicates approximately 2$8 \%$ of pregnancies. Although the outcome is often good, these are important causes of morbidity and mortality for the mother and her child. ${ }^{5}$ In developing countries, prevalence of preeclampsia ranges from $1.8 \%$ to $16.7 \% .^{6}$

Preeclampsia is the main maternal risk factor associated with low birth weight babies and foetal growth restriction ${ }^{1}$. It is considered to be a state of uteroplacental perfusion deterioration with inadequate blood supply to foetus which results in foetal exposure to hypoxic or oxidative stress in the placenta. In response to this stress, the hypoxic placenta releases certain factors into maternal blood which being vasoactive alter the permeability of tension, brings in compensatory mechanisms that lead to an increase in erythrocytes with an increase in erythroblasts ${ }^{3}$ and an elevation in the counts of nucleated RBCs. ${ }^{3}$ Production of red cells or erythropoiesis, is a tightly regulated process by which hematopoietic stem cells differentiate into erythroid progenitors and then mature into red cells. ${ }^{8}$

Reticulocyte is a young erythrocyte that contains no endoplasmic reticulum but retains mitochondria, small number of ribosomes, the centriole and remnants of the Golgi apparatus. Supravital staining with new methylene blue or brilliant cresyl blue produces aggregates of ribosomes, mitochondria and other cytoplasmic organelles. These artifactual aggregates of the reticulocyte stain deep blue and, arranged in reticular strands, give the reticulocyte its name. Maturation of circulating reticulocyte requires 24 to 48 hours. ${ }^{9}$ Reticulocytes comprise less than $1 \%$ of circulating red blood cells in adults, ${ }^{10}$ in neonates $2-6 \%$ and in children $0.5-2 \% .^{11}$

The Reticulocyte Production Index is a marker for erythropoietic output. It estimates the quantity of reticulocytes in peripheral blood corrected for the degree of anaemia. It is, therefore, a good measure of whether the 
reticulocyte production is adequate for the degree of anaemia. ${ }^{8}$ Since, there is an increase in erythroblasts, there should consequently be an increase in reticulocytes as the erythroblasts mature into reticulocyte first and thereafter into new RBCs. This should lead to an increase in the reticulocyte production index which indirectly indicates bone marrow activity. Thus, RPI can prove to be effective marker of foetal compromise in patients.

\section{Aims and Objectives}

To study and compare the hematological parameters in umbilical cord blood of neonates born to preeclamptic and normal mothers.

\section{Material and Methods}

This study is a cross sectional study, conducted in the Department of Physiology in collaboration with the Department of Obstetrics and Gynaecology and Department of Pathology of Era's Lucknow Medical College and Hospital (ELMCH), Lucknow. Period of study was 18 months. The study was carried out to compare the hematological parameters of neonates born to preeclamptic and normal mothers. 40 cases and 40 controls were taken in each group.

\section{Inclusion Criteria:}

CASES: neonates from preeclamptic pregnancies delivered in ELMCH, Lucknow

CONTROL: neonates from normal healthy pregnancies delivered in ELMCH, Lucknow

\section{Exclusion Criteria: Subjects}

1. who did not deliver in Era's Lucknow Medical College and Hospital

2. who have had any chronic diseases

3. who had a previous blood transfusion

4. who had a history of recent infections

5. with an ABO incompatibility

6. with an $\mathrm{Rh}$ incompatibility

7. who had bleeding disorders of any kind

8. who did not give consent

\section{Method}

All the patients fulfilling the inclusion criteria and not falling into the domain of exclusion criteria were invited to enroll in the study till the sample size requirements were fulfilled. All patients were explained about the protocol of the study and a written informed consent was obtained. After enrolment a general and systemic exam was done with special emphasis on blood pressure of pregnant women. Urine of mothers was analyzed for presence of proteins using Urinary Dipsticks. In this study the umbilical cord blood sample of neonates (2 ml) was taken at birth for both cases and controls. All the blood samples were collected in EDTA coated vials and were analyzed using the automated cell counter machine (SYSMEX KX 21) placed in the Hospital Laboratory Service (HLS) for Haemoglobin, Haematocrit, Red Blood Cells estimation. Birth weight of the baby was noted in kilograms. A smear was made for analyzing reticulocytes using the supravital stain Brilliant Cresyl Blue.

Reticulocyte Production Index was calculated using a normal hematocrit of 45 using the formula:

RPI: (Reticulocyte \%* HCT)/ Normal HCT (45) Maturation factor

Hematocrits and corresponding maturation correction factors are as follows:

1. Hematocrit 40-45 :Factor of 1

2. Hematocrit35-39: Factor of 1.5

3. Hematocrit 25-34:Factor of 2

4. Hematocrit15-24: Factor of 2.5

5. Hematocrit $<15$ : Factor of 3

\section{Statistical Analysis}

The data so collected was subjected to statistical analysis using Statistical Package for Social Sciences (SPSS) version 16.0. To compare the means of haematological values (between cases and controls) paired ' $t$ ' test was used. To compare means of birth weight of neonates both in case and control group also paired ' $t$ ' test was used. The confidence limit of the study was kept at $90 \%$ hence a ' $p$ ' value less than 0.05 was considered to be statistically significant. Generation of graphs and tables were done by Microsoft Excel and Microsoft Word version 2007.

\section{Observation and Results}

Table 1 shows gender distribution of newborns in Study and Control group. In the control group 12 newborns $(30 \%)$ are males and 28

newborns $(70 \%)$ are females. In the Study group 14 new borns $(35 \%)$ are males and $26(65 \%)$ are females.

Table 2 shows that in the Study group 12 newborns $(30 \%)$ were below 2.5 kilograms and 28 newborns $(70 \%)$ were above 2.5 kilograms. In the control group 7 newborns $(17.5 \%)$ were below 2.5 kilograms and 33 newborns $(82.5 \%)$ were above 2.5 kilograms. There was a significant difference in the outcome of babies in terms of birth weight in preeclampsia when 
compared to normal healthy pregnancies ( $p$ value $<0.001)$.

In Table 3, in newborns of Study group the mean \pm SD of Total Red Blood Cell count (TRBC) is $4.797 \pm 0.40 \times 10^{6} / \mu \mathrm{L}$. In newborns of the control group it is $4.666 \pm 0.42 \times 10^{6} / \mu \mathrm{L}$.
Comparing between the means of the Study and control groups

the ' $t$ ' value is 1.365 and the association is statistically not significant ( $p$ value $>0.05$ ). Fig. 1 shows distribution of Total Red Blood Cells count in Study and Control Groups in newborns.

Table 1: Gender wise Distribution of new born in Study and Control Group

\begin{tabular}{|c|c|c|c|c|}
\hline \multirow{3}{*}{ Gender } & \multicolumn{2}{|c|}{$\begin{array}{c}\text { Cases } \\
(\mathbf{n = 4 0})\end{array}$} & \multicolumn{2}{c|}{$\begin{array}{c}\text { Controls } \\
(\mathbf{n = 4 0})\end{array}$} \\
\cline { 2 - 5 } & No. of new born & $\%$ & No. of new born & \% \\
\hline Male & 14 & 35 & 12 & 30 \\
\hline Female & 26 & 65 & 28 & 70 \\
\hline
\end{tabular}

Table 2: Birth weight distribution of newborns in Study and Control groups

\begin{tabular}{|c|c|c|c|c|c|c|c|c|}
\hline & \multicolumn{3}{|c|}{$\begin{array}{c}\text { Cases } \\
(n=40)\end{array}$} & \multicolumn{3}{|c|}{$\begin{array}{c}\text { Controls } \\
(n=40)\end{array}$} & $\begin{array}{c}T \\
\text { value }\end{array}$ & $\begin{array}{c}p \\
\text { value }\end{array}$ \\
\hline & $\begin{array}{c}\text { No. of } \\
\text { newborns }\end{array}$ & $\%$ & $\begin{array}{c}\text { MEAN } \\
\pm \text { SD }\end{array}$ & $\begin{array}{c}\text { No. of } \\
\text { newborns }\end{array}$ & $\%$ & $\begin{array}{c}\text { MEAN } \\
\pm \text { SD }\end{array}$ & & \multirow[b]{3}{*}{0.001} \\
\hline B. Wt<2.5 kgs & 12 & $30 \%$ & \multirow[b]{2}{*}{$\begin{array}{c}2.617 \pm \\
0.27\end{array}$} & 7 & $17.5 \%$ & \multirow[b]{2}{*}{$\begin{array}{c}2.813 \pm \\
0.19\end{array}$} & & \\
\hline B. $W \mathrm{t} \geq 2.5 \mathrm{kgs}$ & 28 & $70 \%$ & & 33 & $82.5 \%$ & & 3.625 & \\
\hline
\end{tabular}

Table 3: Distribution TRBC, Hb, Hct, Retic count and RPI in study and control Group

\begin{tabular}{|c|c|c|c|c|}
\hline & $\begin{array}{c}\text { Cases } \\
(n=40) \\
\end{array}$ & $\begin{array}{c}\text { Controls } \\
(n=40)\end{array}$ & & \\
\hline & MEAN \pm SD & MEAN \pm SD & $t$ value & $p$ value \\
\hline TRBC $\left(10^{6} / \mu \mathrm{L}\right)$ & $4.797 \pm 0.40$ & $4.666 \pm 0.42$ & 1.365 & 0.180 \\
\hline Haemoglobin (in g/dL) & $16.36 \pm 1.40$ & $16.50 \pm 1.33$ & -0.417 & 0.679 \\
\hline Haematocrit (in \%) & $49.385 \pm 4.19$ & $49.460 \pm 4.47$ & -0.073 & 0.942 \\
\hline Reticulocyte Count (in \%) & $6.68 \pm 1.10$ & $4.58 \pm 1.11$ & 7.714 & $<0.001$ \\
\hline $\begin{array}{l}\text { Reticulocyte Production Index } \\
\text { (RPI) }\end{array}$ & $7.297 \pm 1.22$ & $4.957 \pm 1.20$ & 8.454 & $<0.001$ \\
\hline
\end{tabular}

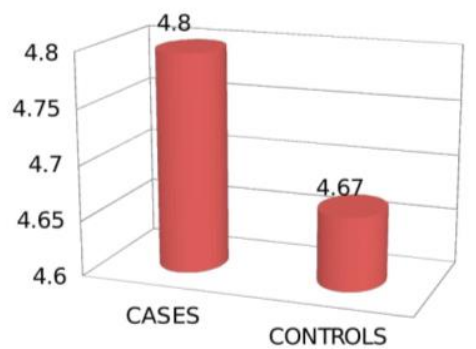

Fig. 1: Distribution of total red blood cells count in study and control groups in newborns

In Table 3 Haemoglobin mean \pm SD in study group is $16.36 \pm 1.40 \mathrm{~g} / \mathrm{dL}$ for newborns. In the control group mean $\pm \mathrm{SD}$ is $16.50 \pm 1.33 \mathrm{~g} / \mathrm{dL}$. Comparing between the means of the cases and controls, the $t$ value is -0.417 and the association is statistically not significant ( $p$ value $>0.05$ ). Haematocritmean \pm SD in study group is $49.385 \pm 4.19 \%$ for newborns. In the control group Mean \pm SD is $49.460 \pm 4.47 \%$. Comparing between the means of the cases and controls, the
' $t$ ' value is -0.073 and the association is statistically not significant ( $p$ value $>0.05$ ).

In the present study, the values of Haematocrit as in Table $\mathbf{3}$, in case group $(33.498 \pm 3.26 \%)$ is lower than that in the control group $(49.460 \pm 4.47 \%)$ and the difference is statistically insignificant ( $\mathrm{p}$ value $>0.05$ ). This is contradictory to the findings of Catarino $\mathrm{C}$ et al in 2008 , in their study in which, they stated an increase in the hematocrit values of neonates from preeclamptic pregnancies [47.2(44.5;50.8)\%] compared to those of neonates from the control group [45.9(43.2;49.6)\%] but the difference was statistically insignificant $(\mathrm{p}=0.28) .{ }^{4,19} \quad$ This difference in observations of the abovementioned studies could possibly be due to increased / decreased number and/or size of red blood cells in cord blood, regional differences or due to differences in sample size of different studies.

Table 3 shows Reticulocyte mean \pm SD in Study group is $6.68 \pm 1.10 \%$ for newborns. In the control group Mean $\pm \mathrm{SD}$ is $4.58 \pm 1.11 \%$. 
Fig. 2 shows distribution of Reticulocyte count in Study and Control Group of newborns. Comparing between the means of the case and control groups, the ' $t$ ' value is 7.714 and the association is statistically significant ( $p$ value $<0.05)$.

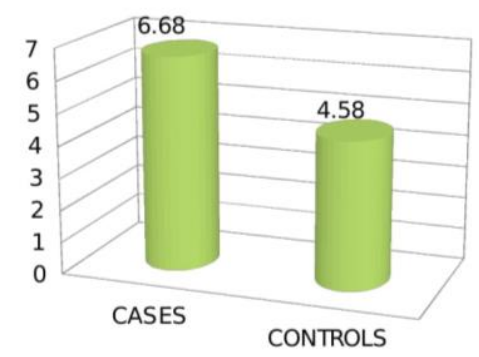

Fig. 2: Distribution of Reticulocyte count in Study and Control Group of newborns

Looking at the Reticulocyte Production Index, the mean $\pm \mathrm{SD}$ in the Study group is $7.297 \pm 1.22$. In the control group mean $\pm \mathrm{SD}$ is $4.957 \pm 1.20$. Comparing between the means of the cases and controls, the ' $t$ 'value is 8.454 and the association is statistically significant ( $p$ value $<0.05)$. Fig. 3 shows distribution of Reticulocyte Production Index (RPI) in study and control groups for newborns.

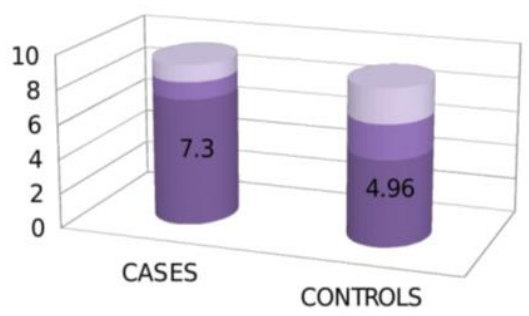

Fig. 3: Shows distribution of Reticulocyte Production Index (RPI) in study and control for newborns

\section{Discussion}

Preeclampsia is more prevalent in both developed and developing countries contributing to maternal and perinatal morbidity and mortality globally. The clinical findings of preeclampsia can manifest either as a maternal syndrome (hypertension, proteinuria with or without edema and other multisystem abnormalities) or as a foetal syndrome (foetal growth restriction, reduced amniotic fluid and abnormal placentation). ${ }^{12}$

The sole source of nutrients for the growing foetus is the maternal blood. ${ }^{13}$ Cord blood is the true indicator of haematological values at birth as it is not affected by hemodynamic changes that take place within a few hours of birth. ${ }^{14}$

With this background, the present study was carried out to evaluate the changes in haematological parameters in umbilical cord blood of neonates born to preeclamptic mothers compared to those born from a normal healthy pregnancy.

In the present study, birth weight in the case group $(2.617 \pm 0.27 \mathrm{kgs})$ was found to be significantly lower than the birth weight in the control group $(2.813 \pm 0.19 \mathrm{kgs})$ (p value $<0.05)$. This is in accordance with the study done by $\mathrm{Al}$ Bayati et al in the year 2011 where they also showed lower birth weight in neonates born to preeclamptic women (2920.20 \pm 488.37 grams) than those from normal healthy pregnancies (3248 \pm 279.39 grams), the difference being statistically significant $(\mathrm{p}<0.001) .{ }^{15}$ Similarly, a study done by Hebbar $\mathrm{S}$ et al in the year 2014 also showed lower birth weights in neonates from preeclamptic mothers $(2171 \pm 805.3$ grams $)$ compared to those from normal healthy pregnancies (2976.1 \pm 473.3grams) which was also statistically significant $(\mathrm{p}<0.001) .{ }^{16}$

In the present study, the Total Red Blood Cell count of neonates in case group $(4.797 \pm 0.40$ $\mathrm{X} 10^{6} / \mu \mathrm{L}$ ) was higher than the Total Red Blood Cell count of neonates in the control group $\left(4.666 \pm 0.42 \times 10^{6} / \mu \mathrm{L}\right)$. The difference of means of the two groups was statistically not significant ( $\mathrm{p}$ value $>0.05$ ). In another study done by Bolat A et al in 2013 also, significantly higher RBC counts in neonates from preeclamptic pregnancies $\left[4.4 \pm 0.3(3.8-5.4) \times 106 / \mathrm{mm}^{3}\right]$ were observed than those from normal healthy pregnancies $\left[4.1 \pm 0.4(3.3-4.9) \times 10^{6} / \mathrm{mm}^{3}\right]$ which was statistically significant $(\mathrm{p}=0.02) .{ }^{17}$ These results stand in contradiction to those observed in the study done by Catarino C et al in 2008, where a decrease in the RBC values of neonates from preeclamptic pregnancies[4.3(4.0;4.7) $\left.\mathrm{X} 10^{12} / \mathrm{L}\right]$ compared to those of controls $\left[4.4(4.1 ; 4.6) \times 10^{12} / \mathrm{L}\right]$ was observed though the difference was statistically insignificant $(\mathrm{p}=0.38) .{ }^{4}$ Difference in the findings of the aforementioned studies could be possibly due to differences in nutritional, environmental factors and also due to different geographical locations of the subjects in different studies.

In the present study, the value of Haemoglobin in case group $(16.36 \pm 1.40 \mathrm{~g} / \mathrm{dL})$ is lower than that in the control group $(16.50 \pm 1.33$ $\mathrm{g} / \mathrm{dL}$ ) but the difference was not statistically significant ( $\mathrm{p}$ value $>0.05$ ). This is contradictory to the results observed by Bolat A et al in 2013 in their study, in which they showed higher haemoglobin levels in neonates born to 
preeclamptic mothers [16.1 $\pm 1.4(14.4-19.3) \mathrm{g} / \mathrm{dL}]$ than those born to normotensive mothers $[15.2 \pm 1.1(12.9-17.7) \mathrm{g} / \mathrm{dL}]$ and the difference between means of the two groups was statistically significant $(\mathrm{p}=0.004)^{17}$. In another study done by Sivakumar et al in the year 2007 , Haemoglobin was found to be high in cord blood in neonates from preeclamptic pregnancies(17.98 $\mathrm{g} / \mathrm{dL})$ than from normal healthy pregnancies $(17.33 \mathrm{~g} / \mathrm{dL})$, but was statistically insignificant $(p>0.05)^{18}$. In a study by Catarino $C$ et al in 2008, they stated an increase in the haemoglobin values of neonates from preeclamptic pregnancies $[16.0(14.7 ; 17.2) \mathrm{g} / \mathrm{dL}]$ than those from controls $[15.5(14.8 ; 16.2) \mathrm{g} / \mathrm{dL}]$ which was statistically insignificant $(\mathrm{p}=0.28) .{ }^{4,19}$ These differences could be attributable to the differences in time of cord clamping (early or delayed) in different studies or due to environmental factors and others such as poverty and malnutrition.

In the present study, the values of Haematocrit in case group $(33.498 \pm 3.26 \%)$ is lower than that in the control group $(49.460 \pm 4.47$ $\%)$ and the difference is statistically insignificant ( $\mathrm{p}$ value $>0.05$ ). This is contradictory to the findings of Catarino $\mathrm{C}$ et al in 2008, in the study in which, they stated an increase in the hematocrit values of neonates from preeclamptic pregnancies [47.2(44.5;50.8)\%] compared to those of neonates from the control group $[45.9(43.2 ; 49.6) \%]$ but the difference was statistically insignificant $(\mathrm{p}=0.28) .{ }^{4,19} \quad$ This difference in observations of the abovementioned studies could possibly be due to increased / decreased number and/or size of red blood cells in cord blood, regional differences or due to differences in sample size of different studies.

In the present study, the Reticulocyte Count in case group $(6.68 \pm 1.10 \%)$ is higher than that in the control group $(4.58 \pm 1.11 \%)$ and the difference is statistically significant ( $p$ value<0.05). It is in accordance with the study done by Bolat A et al in 2013, in which they showed significantly higher reticulocyte count $[5.7 \pm 2.7(3.6-15) \%]$ in neonates of case group than those of the control group $[3.3 \pm 1.6(1-8) \%]$ which was statistically significant $(\mathrm{p}<0.001) .{ }^{17}$ In a study in 2008 by Catarino $\mathrm{C}$ et al also showed significant increases in Reticulocyte counts in neonates from preeclamptic pregnancies $\left[158(138.1 ; 205.3) \times 10^{9} / 1\right]$ than those from healthy controls[154(96.6;191.2) x109/1] $(\mathrm{p}=0.048) .^{4,19}$ In a study in 2014 by Rawat A et al also showed significant increases in Reticulocyte counts in neonates from preeclamptic pregnancies (7.1219 \pm 1.0699$]$ than those from healthy controls $\left(3.0457 \pm 1.6240(\mathrm{p}<0.0001){ }^{20}\right.$
In the present study, the values of Reticulocyte Production Index in case group $(7.297 \pm 1.22)$ is higher than that in the control group $(4.957 \pm 1.20)$ and the difference is statistically significant ( $\mathrm{p}$ value $<0.05)$. This stands in accordance with the study done by Catarino $\mathrm{C}$ et al in the year 2008 in which they showed significant increases in Reticulocyte Production index in neonates from preeclamptic pregnancies[4.00(3.20;5.20)] than those from healthy controls[3.40(2.20;4.60)]..$^{4,19}$

\section{Conclusion}

At the end of the study the following conclusions were drawn:

1. In our study, $35 \%$ neonates in the study group were males and $65 \%$ were females while in the control group $30 \%$ neonates were males and $70 \%$ were females. Birth weight in the study group was found to be significantly lower than the birth weights in the control group which is statistically significant $(\mathrm{p}<0.05)$. In the case group $30 \%$ neonates presented with birth weight less than 2.5 kilograms while in the control group $17.5 \%$ neonates presented with a birth weight of less than 2.5 kilograms.

2. The Total Red Blood Cell count (TRBC) in study group is higher than that of control group in neonates but the difference is statistically insignificant(p value $>0.05)$. Haemoglobin values in study group is lower than that of control group in neonates (statistically insignificant with $\mathrm{p}$ value $>0.05)$. Haematocrit in study group is also lower than that of control group in neonates (difference being statistically not significant with $\mathrm{p}$ value $>0.05$ ).

3. The Reticulocyte Count is higher in study group than in controls and it is statistically significant ( $p$ value $<0.05)$ Also, RPI is higher in study group than in controls and it is also statistically significant ( $p$ value $<0.05)$.

\section{References}

1. Catarino C, Rebelo I, Beloi L, Quintanilha A, Santos-Silva A. Umbilical Cord Blood Changes in Neonates from a Preeclamptic Pregnancy, from preconception to Postpartum, Dr. Stavros Sifakis (Ed.), ISBN:978-953-51-0353-0, In Tech.

2. Dutta DC:Textbook of Obstetrics: 6th Edition 2004:Ch 17:pages 221-42.

3. Aali BS, Malekpour R, Sedig F, Safa A. Comparison of maternal and cord blood nucleated red blood cell count between pre-eclamptic and healthy women. J Obstet Gynaecol. 2007;33(3):274-8. 
4. Catarino C, Rebelo I, Beloi L, Petronila R P, Rocha S, Castro EB, Belmiro P, Quintanilha A, Santos-Silva A. Erythrocyte Damage Aging/Removal Are Enhanced In Both Mother And Fetus, In Preeclampsia. Actas Bioq. 2008,9:63-7.

5. The Magpie Trial Collaborative group. Do women with pre-eclampsia, and their babies, benefit from magnesium sulphate? The Magpie Trial: a randomised placebo controlled trial. The Lancet 2002;359(9321):1877-90.

6. Osungbade KO, Ige OK. Public Health Perspectives of Preeclampsia in Developing Countries: Implication for Health System Strenghtening. Journal of Pregnancy, 2011; Article 1D481095.

7. Crosbie E, Heazell A, Pickersgill A, Slade R. Preeclampsia and eclampsia. In. Key Clinical Topics in Obstetrics \& Gynaecology. ,2014, JP Medical Ltd; pages 290-3. ISBN: 978-1-90781670-3.

8. Prchal JT. Production of Erythrocytes. In. Lichtman MA, Kipps TJ, Selighson U, Kaushansky K, Prchal JT, eds. Williams Hematology. $8^{\text {th }}$ ed. McGraw-Hill: NewYork;2010:Chapter 31.

9. Morphology of Erythron. In. Lichtman MA, Kipps TJ, Selighson U, Kaushansky K, Prchal JT, eds. Williams Hematology. $8^{\text {th }}$ ed. McGraw-Hill: NewYork;2010:Chapter 29.

10. Hall JE. Erythropoiesis.In.Vaz M,Kurpad A, Raj T, eds. Guyton And Hall: Textbook of Medical Physiology. A South Asian edition. Elseviers.Ch. 20;pages 112-3.

11. Ghai OP, Paul VK, Bagga A: Ghai's Essential Pediatrics: $7^{\text {th }}$ edition 2009; Ch.11:p 296-301.

12. Ankita Gawde, U. T. Bhosale. A Study of Maternal and Perinatal Outcome in Preeclampsia. International Journal of Recent Trends in Science And Technology 2014; Volume 10, Issue 2, 2014 pp 267-70; ISSN 2277-2812 E-ISSN 2249-8109

13. Babay ZA, Addar MH, Warsy AS, ElHazmimMA The inter-relationship haematological parameters between Saudi newborns and parents Saudi Med J 2002;Vol. 23 (8):943-6.

14. Kumar A, Singh J, kumar I. To study the relation of anthropometric factors with total and differential leucocyte count in healthy newborns. Pediatric Review: International Journal of Pediatric Research. July, 2016; Vol 3:Issue 7;52732; ISSN 2349-5499.

15. Al-Bayati MM, Jameel BS, Suhial TM, Melkon AA. Maternal and Cord Blood Nucleated Red Blood Cells Count in Women with Preeclampsia. Iraqi J Comm. Med, 2011;24(4):302-7.

16. Shripad Hebbar, Mehak Misha, and Lavanya Rai. Significance of Maternal and Cord Blood Nucleated Red Blood Cell Count in Pregnancies Complicated by Preeclampsia. Journal of Pregnancy. Volume 2014, Article ID 496416;1-7.

17. Bolat A, Gursel 0, Kurekci E, Atay A, Ozcan O. Blood parameters changes in cord blood of newborns of hypertensive mothers. Eur $J$ Pediatr,2013;172:1501-9.

18. Sivakumar S, Vishnu Bhat B, Badhe BA. Effect of Pregnancy Induced Hypertension on Mothers and their Babies. Indian J Pediatr 2007;74(7):623-5.

19. Catarino C, Rebelo I,Belo L, , Petronila RochaPereira P, Rocha S, Castro E, Patricio B Quintanilha A, Santos-Silva A. (2009b). Erythrocyte changes in Preeclampsia: relationship between maternal and cord blood erythrocyte damage. J Perinat Med, Vol. 37, No.1, pp 19-27, ISSN 1744-165X.

20. Rawat A, Srivastava N, Gangwar A, Tiwari S, Srivastava P. A Study Of Reticulocyte Count In The Cord Blood Of Preeclamptics And Healthy Pregnant Women. Indian J PhysiolPharmacol 2014;58(2):182-3. 